This is a self-archived version of an original article. This version may differ from the original in pagination and typographic details.

Author(s): Elmgren, Heidi

Title: Hindrances to recognition in Finnish music schools

Year: 2021

Version: Accepted version (Final draft)

Copyright: @ 2021 SAGE

Rights: In Copyright

Rights url: http://rightsstatements.org/page//nC/1.0/?language=en

Please cite the original version:

Elmgren, H. (2021). Hindrances to recognition in Finnish music schools. International Journal of Music Education, 39(2), 202-217. https://doi.org/10.1177/0255761420986223 


\section{Hindrances to recognition in Finnish music schools ${ }^{12}$}

Journal: International Journal of Music Education

Manuscript ID: IJME-RS-19-0080.R1

Manuscript type: Original article

Keywords: Music education, respect, esteem, recognition relations, Axel Honneth, Dominique Girardot

Abstract: This article examines recognition relations between students and teachers in Finnish music schools. The research is based on written texts by music school students. The texts are analysed for difficulties in recognition relations, namely, hindrances to recognition in music schools. In the texts, some of the respondents describe situations that can be analysed as hindrances to recognition. The author analyses four different types of recognition-related problems in the data, the main issue being a tension between caring for people (respecting them) and promoting musical values (emphasising esteem). In addition to discerning problems, the article attempts to alleviate this tension. This might be achieved if different kinds of excellence, rather than just one, were to be developed in music schools. Students' different abilities and motivations might then have a chance to emerge. Caring for people in the context of studying music would mean helping them to find the musical values they can and want to promote.

\section{Introduction}

In this article, I examine recognition relations (Girardot, 2011; Honneth, 1995) between students and teachers in Finnish music schools. I analyse difficulties in achieving recognition, which I dub hindrances to recognition. Recognition refers to people's need to be recognised in different ways by others; recognition relations describe relations between people where recognition is either granted or denied. I base my study on written texts that I collected online from current and former students at Finnish music schools during the autumn of 2015 and the winter of 2016. I analyse the data from the viewpoint of theory-driven qualitative content analysis (Alasuutari, 2012; Silvasti, 2014). invaluable

This article makes an empirical application of some of these ideas, examining recognition relations in Finnish music schools for children and young people. The theoretical framework

\footnotetext{
${ }^{1}$ This publication has been undertaken as part of the Philosophy and Politics of Recognition project, funded by the Cultural Foundation of Finland.

${ }^{2}$ I wish to thank the anonymous reviewers for their insightful comments which have greatly improved the quality of this article. Thank you also to Onni Hirvonen, the head of the Philosophies and Politics of Recognition project, and to Arto Laitinen who commented an early version of this article. I also owe special thanks to our virtual seminar, that is, to researchers Suvi Kouri, Annukka Lahti, Laura Mankki, Armi Mustosmäki, Tiina Sihto, Jenny Säilävaara and Paula Vasara for their invaluable comments and encouragement.
} 
that recognition theory provides helps us to grasp the process of learning holistically, that is, as tied to a person's sense of self-value and their beliefs concerning themselves, rather than as simply the intellectual activity of gaining certain skills.

\subsection{Context: the Finnish music school system}

By music schools, I refer to Finland's partially state-funded institutions for the musical education of children and young people (aged roughly six to 18 years), which takes place as an extracurricular activity. Music schools where music (instruments, music theory, orchestra practice etc.) is taught as a leisure activity are common in European countries: the Association of Finnish Music Schools is part of the European Music School Union, which represents 26 national member associations and over 6,000 music schools in Europe (Riediger et al., 2010). There are 96 music schools in Finland (Suomen Musiikkioppilaitosten liitto, 2017), and in total $4.6 \%$ of those aged seven to 19 take part in music education (in some parts of Finland the participation rate is as high as $7.9 \%$ of this age group) (Aluehallintovirasto, 2012). ${ }^{3}$

The curricula in music schools are authorised by the Finnish National Agency for Education (Alt et al., 2017). Music schools have a strong standing in Finnish arts education, and that standing is reinforced by various laws (particularly the Law Concerning Basic Education in the Arts, 1998/633; for a more detailed overview of the legal process, see Kangas \& Halonen, 2015, pp. 199-200). Basic education in the arts concerns various fields of the arts, ${ }^{4}$ and by law it 1) is target-oriented, 2) advances from one level to the next, and 3) is organised primarily for children and young people. It prepares students to 4) express themselves and 5) apply for professional training in their chosen field (Law Concerning Basic Education in the Arts, 1998/633). This music education is available in 140 of 295 municipalities ${ }^{5}$ (Aluehallintovirasto, 2012).

\footnotetext{
3 The percentage of children and young people that take part in basic education in the arts (which includes music among other things) is $12 \%$. Basic education in music is also given outside music schools (e.g. in community colleges), but the focus of this study is on music schools.

${ }^{4}$ Specifically, architecture, circus arts, dance, handicrafts, literary arts, media arts, music, visual arts, and theatre.

5 The total number of municipalities in Finland is 311, but the Åland Islands are not included in statistics concerning basic education in the arts.
} 
In music schools, students advance through course examinations to complete their diplomas. The completion of diplomas enables students to apply for professional musical training. In most music schools, students are selected on the basis of an entrance examination. Depending on the area, up to $50 \%$ of applicants may not be accepted (Kangas \& Halonen, 2015, p. 203). The exact content of the examination varies from one institution to another.

\subsection{Theoretical background: recognition theory}

In this article, I study how music school students' experiences resonate with different recognition theories, namely those of Dominique Girardot (2011) and Axel Honneth (1995; see also Fraser, 2003; Väkevä, 2013). Through a call for contributions, I asked former and current music school students to write about their good and bad experiences at music school in relation to being included or excluded. Some of their responses give us answers as to whether these students felt recognised or not in their music schools.

Recognition can be divided into three categories or patterns of recognition: love, respect and esteem (Honneth, 1995). Love, or emotional support, is the model of intimate relationships such as friendships, love relationships and parent-child relationships. Cognitive respect refers for example to legal relationships where respect is shown through the guarantee of legal rights and the treatment of people as equals. The third pattern of recognition is social esteem. This entails the recognition of personal traits and abilities by the community of value (Honneth, 1995, pp. 92-130). Here I consider how respect and esteem are granted (or not) in a music school context. Esteem is especially important here, as recognising students often means recognising their musical abilities. However, the two other patterns of recognition are also relevant in music schools. In this article, in addition to esteem, I have chosen to analyse respectrelated issues, as they enable us to look beyond the explicit, legally imposed goal of music education - i.e. the acquisition and development of skills - and allow us to focus on questions of equal treatment.

I have already outlined possible recognition-related problems in previous articles (Elmgren, 2015, 2018) based on the work of French philosopher Dominique Girardot (2011). Here I examine how some of these issues - namely, opportunities to attain distinction, the reification of merit and the threat of instrumentalisation - are manifest in the music school context 
(sections 2.1-2.3). In a previous theoretical article, I studied the importance of having one's achievements recognised as distinct. I argued that it is essential to be able to pursue distinction - that is, original excellence - rather than just standard performance, and to have these activities and their results recognised as distinct (see Elmgren, 2015; Girardot, 2011). In this article, I analyse respondents' answers from the viewpoint of their opportunities to attain distinction at music school.

By showing that there are problematic ways of realising recognition relations in music schools that are linked to institutional values and practices, I aim to initiate the first phase of what Arvi Särkelä (2008) has called the process of the struggle for recognition. He describes this first phase where 'a recognitive relation and habitual attitude can become thematised as problematic, because it is experienced as involving domination or wronging or else as bad'. I demonstrate that some practices described by my respondents are examples of recognition relations involving teachers' domination over students, and the wronging of some students due to unfair treatment in ways that are connected to recognition. By pointing out these problems, I wish to create possibilities to reconcile them so that successful recognition can be attained (Särkelä, 2008). More harmoniously realised recognition relations would create more participatory parity among music school students (see Fraser, 2003).

The term pathologies of recognition has been used in the contemporary literature to describe the harmful, hindering and disruptive forms that recognition relationships might take (see e.g. Hirvonen, 2018; Ikäheimo, 2015; Laitinen, 2015). Pathologies of recognition are defined as institutional, processual problems in recognition relations (see Särkelä, 2008; Laitinen et al., 2015). I have chosen not to use the term pathology in this article. Instead, I use the term hindrance. The normative and stigmatising connotations of the word pathology make it problematic in this empirical context, and might cause undue harm to the institutions implicated in my study. There are also conceptual problems linked to the notion (Freyenhagen, 2015).

\subsection{Previous research}

Recognition theory has been utilised in education, especially in the field of adult education and in the context of lifelong learning over the past 25 years (see e.g. Andersson \& Fejes, 2010; 
Fleming, 2014; Hanhela, 2014; Huttunen, 2009; Sandberg, 2016; Sprung, 2013; Stojanov, 2018). According to Stojanov (2018, p. 88), 'relations like empathy, respect and social esteem have a particularly strong educative impact'; he even refers to results in educational neuroscience (i.e. Immordino-Yang \& Damasio, 2007; Blodget et al., 2011) that confirm the importance of empathy in teaching and learning (Stojanov, 2018, p. 100, n. 96). Studying recognition relations in education helps us to discern, for instance, ways of teaching that do not feature domination and which thus create better conditions for the development of the student's identity. Following Honneth, Hanhela (2014, p. 60) explicates the relationship between forms of recognition and the development of one's relationship to oneself as follows: 'love ... enables the development of self-confidence; rights [or respect] ... enables the development of self-respect; and social esteem ... enables the development of self-esteem'. Support for the development of these relationships is arguably essential to any type of education - especially when the students are young and still growing, as is the case in music schools.

To date, no empirical research concerning recognition relations has yet been conducted in the field of music education. In his theoretical and normative article, Lauri Väkevä (2013) analyses how love, respect and esteem can present themselves in the relationship between an instrument teacher and a student in a music school, and how the struggle for recognition can manifest itself in this relationship. Väkevä aims to explicate that there is an obligation on the teacher to recognise the student. I use Väkevä's work as the starting point for my analysis, but I disagree with some of his conclusions.

\subsection{Research questions, data, methods, and limitations of the study}

This article studies recognition relations in music schools: the opportunities for students to become recognised at music school, and the dynamics and practices that can create hindrances

\footnotetext{
${ }^{6}$ Stojanov's footnote refers to an online course organised by the Science Media Group at the Harvard-Smithsonian Center for Astrophysics, in association with the Mind, Brain, and Education programme at the Harvard Graduate School of Education, the Brain and Creativity Institute, and the Rossier School of Education at the University of Southern California (Blodget et al. 2011). Indeed, one subsection of this course deals with the importance of emotions in music education: Neuroscience in the classroom: Making connections, Unit 3.1: Music and emotion, https://www.learner.org/series/neuroscience-in-the-classroom/seeing-others-from-the-self/music-andemotion/.
} 
to recognition. I will argue that some of my respondents faced hindrances to recognition, problems in recognition relations, or problems with how recognition is granted in music schools. My research questions are:

1) What experiences of being recognised and/or being left without recognition at music school do the respondents have?

2) What hindrances to recognition are discernible in the respondents' texts?

\subsubsection{Data}

Music school students' experiences are still under-studied in Finland and worldwide. To gain as many inputs as possible, an open questionnaire was set up online for my data collection. The data was collected during the late autumn of 2015 and the winter of 2016. It was gathered online through a call for contributions ${ }^{7}$ published on a University of Jyväskylä webpage, and was distributed mostly via Facebook and on some music-related mailing lists. The survey consisted of an introductory text, a short questionnaire concerning background information, and a space where the respondents could recount their experiences. The scope of the enquiry was limited to the last 20 years, that is, to people who had studied in music schools during the period 1995-2015. There were 117 usable responses. ${ }^{8}$ The respondents are anonymised in this article.

Sixty-nine per cent of the respondents were aged between 21 and 30 years. Most respondents were no longer continuing their studies at music school. Only $12.8 \%$ were male. The lack of male participants results at least partly from the fact that fewer boys than girls go to music school (Aluehallintovirasto, 2012).

Most participants (78.6\%) evaluated their family income level as medium, $18.8 \%$ as low and 2.6\% as high. Based on families' income levels and the respondents' and their parents' education levels (Figure 1), it seems that respondents mostly came from middle-class or upper-

\footnotetext{
${ }^{7}$ For an English translation of the call for contributions, see the Appendix.

${ }^{8}$ I received 120 responses, but some were disqualified because the respondents had not studied during 19952015, or else because they had not provided any background information, making it impossible to ensure that they had studied during that period.
} 
class families. The background of music school students has not been systematically studied, but it is possible that this ratio indicates that middle- and upper-class parents send their children to music school more often than parents from lower classes.

\section{Figure 1}

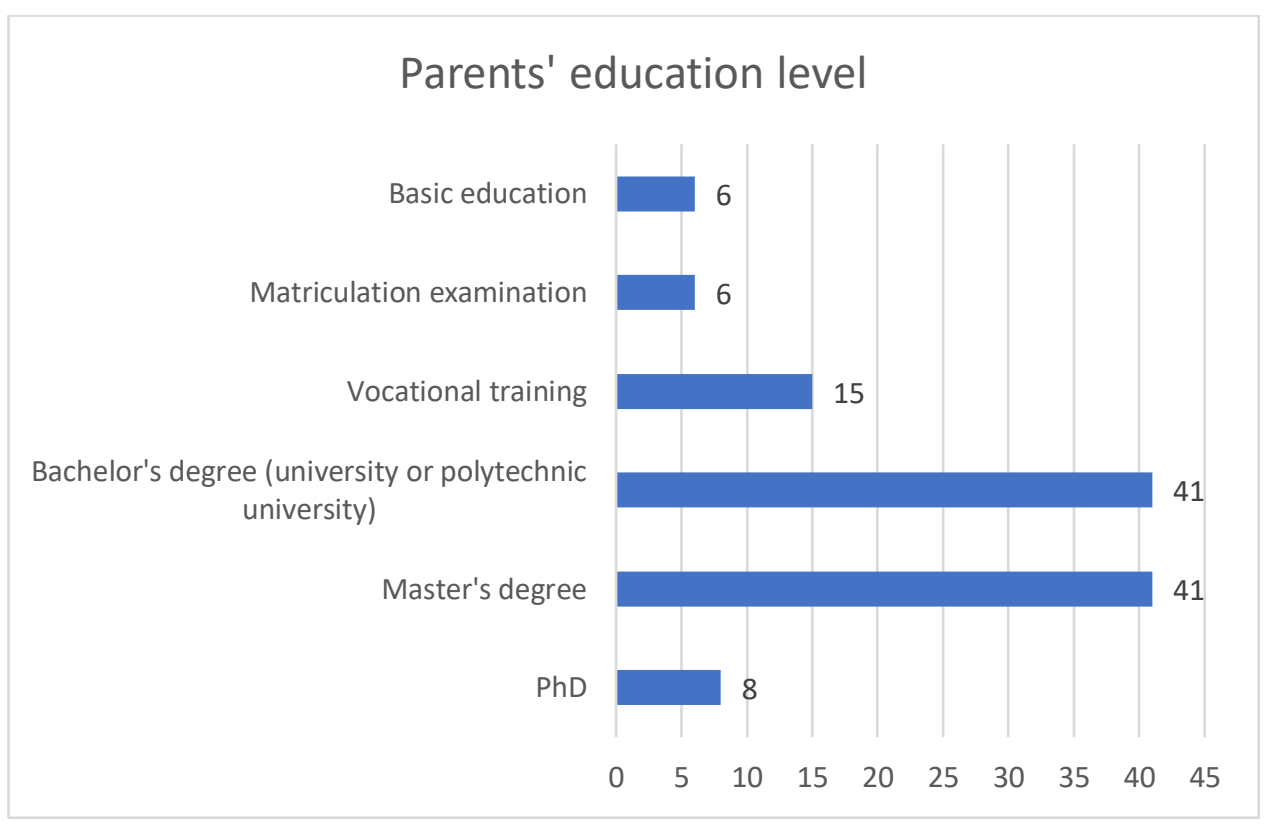

\subsubsection{Method}

The method used to analyse the results was theory-driven qualitative content analysis (Alasuutari, 2012). I can identify some recurring practices and gain an understanding of the way recognition is granted (or not) in music school settings. The hindrances to recognition described here may also apply in other situations, but their occurrence (or non-occurrence) in other music schools cannot be determined from my study alone.

I thematised the data in dialogue with different recognition theories (Girardot, 2011; Honneth, 1995). In this article, I analyse the respondents' writings in relation to three hindrances to recognition: difficulties in attaining distinction (2.1), the reification of merit (2.2) and instrumentalisation (2.3). ${ }^{9}$ I further analyse the implications of the recounted experiences from

\footnotetext{
${ }^{9}$ I chose these three hindrances because one of the remaining three (limiting a subject to factuality) is discussed in my previous article, and the two others do not apply to the music school context. Recognition as remuneration relates more to working life, and the denial of action is a more general societal problem (see Elmgren 2015). The
} 
the perspective of recognition in section 2.4, and I finally proceed to recognition-related problems in institutional hierarchies in music schools (section 2.5).

In the call for contributions (see Appendix), I asked for the respondents to write about positive and negative music school experiences. The answers that I got were varied but most of the longest and the most reflective answers were depictions of negative or conflicting experiences.

As the respondents' texts featured experiences of both being and not being recognised, it was not possible to classify responses as either recognised or not recognised in toto. Instead, I coded the data according to specific traits and depictions of situations where the respondents had felt recognised, overlooked, belittled etc. For example, this included depictions of interactions at music school where a positive or negative evaluation was made of the student, either explicitly or implicitly, and depictions of music school practices that respondents felt enabled (or did not enable) them to be recognised. In the respondents' texts, the theme of recognition circulated around four topics: lack of creativity in music school; perfectionism in music school; hierarchies between students; and recognition as a burden (i.e. the pressures that arise when one is perceived to be 'talented'). The codes I used were creativity, perfectionism, norms, hierarchies and possibilities to choose.

Studying experience is not a self-evident task. The experiences described in this article have already been doubly interpreted: the respondent's formulation is an interpretation of earlier events, and the researcher has then added yet another layer of interpretation by analysing them (see Säilävaara, 2016; Saresma, 2010). Following Saresma (2010), my analysis aims to elucidate how the experiences are formed, and what situations and practices are described in relation to recognition.

\subsubsection{Limitations of the study}

The data collected for this study is based on non-probability sampling, and therefore it is not possible to make decisive remarks about all students in Finnish music schools on the basis of

theme of instrumentalising students is also partly analysed in my previous article (Elmgren 2019), as well as in my doctoral thesis (Elmgren 2020), but here I focus on it from the point of view of recognition relations. 
my findings. The occurrence or non-occurrence of hindrances to recognition in a given music school cannot be determined from my study.

The non-probability sampling also resulted in most of the respondents being aged 21-30 years, and in most of them being female. The survey was mostly distributed through Facebook, which meant most respondents were active Facebook users. This may partly explain why most of the respondents fell into this particular age group: in the United States and United Kingdom, Facebook is more popular among 21-30-year-olds than among under-21-year-olds (Statista 2017a, 2017b). It is likely that the situation is similar in Finland. Music education in Finland is meant for children and young people, so to gain children's viewpoints more research needs to be done in the future. Fewer boys than girls go to music school, and in order to get a clearer view of men's and e.g. gender non-conforming students' experiences in music schools, another, more careful round of data collection with probability sampling would be in order. Also, the effect of the students' social class has not yet been taken into consideration. ${ }^{10}$

Due to the limited scope of the article format, my analysis focuses on only two of the Honnethian patterns of recognition: respect and esteem (sections 2.4 and 2.5). I have excluded love from examination for the time being. Love is also applicable in music school contexts (e.g. in friendships between students, and in the close, positive, even parent-like relationships students sometimes have with their teachers), but it merits its own article. Also, the relationship between creativity, interpretation and classical music is too complicated to address here.

It is crucial to understand that the respondents' interpretations of their teachers' actions are just that: interpretations. From the data, it is not possible to know what the teachers were trying to communicate, or whether they actually 'respected' or 'esteemed' their students. However, it is equally important to understand that the respondents' experiences of not being recognised are still valid. The point of analysing recognition relations is to shed light on the students' ability to interpret different encounters and practices in negative ways and to accumulate negative experiences in doing so. I wish to show that these encounters and practices have consequences

\footnotetext{
${ }^{10}$ I have commenced a class-based analysis of the data, and some interesting tentative results can be drawn. However, as the majority of respondents belong to the middle or upper classes, another round of data collection would be in order to gain more knowledge of the perhaps differing experiences that lower-class students might have of music school.
} 
for the students' motivation to practice and engage in music more generally. The teachers' actions may have been well-meaning, but their consequences may have been different from those intended, as a study of the students' interpretations of them can show.

\section{Analysis}

In my analysis, I will first concentrate on three problems implied by my earlier research on Girardot's consideration of recognition relations. These are difficulties in attaining distinction, the reification of merit and instrumentalisation. I will then go on to consider the Honnethian framework, concentrating on two patterns of recognition, namely respect and esteem.

\subsection{Can one distinguish oneself? Lack of creativity at music school}

In a previous theoretical article (Elmgren, 2015), I studied the importance of having one's achievements recognised as distinct, that is, as simultaneously both original and excellent. In situations where one is trying to attain such distinction, there is a hindrance to recognition if there is no room for personal, non-standard expression, or if such personal expression is not recognised as excellent but instead regarded as inherently flawed.

The legally decreed goal of basic education in the arts is to enable students to 'express themselves' (Law Concerning Basic Education in the Arts, 1998/633). I interpret this to mean that arts education ought to develop students' creativity, or their abilities to express their personality traits, interests, preferences, and/or personal tastes through their hobbies. This might be achieved, for instance, by emphasising students' own musical expression through the practices of improvisation, composition and other kinds of musical experimentation. However, in 2005 such activities were mentioned only briefly in the core curriculum for basic education in the arts, and were not mentioned at all in relation to advanced level. This suggests that they were not widely taught, and my data supports this suggestion. The new core curriculum, issued in 2017, addresses these issues as well as the discrepancy between the law and the practical realities of music schools, but the respondents who answered the survey in 2015 and 2016 were undertaking or had undertaken their studies under the 2005 core curriculum. 
My data reveals that there were cases where personal expression as a goal of study was completely overlooked. Five respondents (4.3\%) write about their institution's negative approach to creativity. Anette (aged 33) writes: 'the music studies did not in any way encourage creativity and independent musical thinking'. Mari (aged 23) writes of the 'elimination of creativity'. For Saara (27), music education was all about concentrating on mistakes and perfect execution, overlooking creativity and experimentation.

In the context of classical music (which was the curriculum followed by most of the respondents, including the five mentioned above ${ }^{11}$ ), this seems to be linked to the Western tradition: the standards of performance are shared almost unanimously wherever Western classical music is taught and played. In their keynote at the Musical Cultures conference in Hull in April 2017, Daniel Leech-Wilkinson and Mine Doğantan-Dack stated:

Classical music performance practice, as a form of art making, [has] remained entirely untouched by the critically reflective and socio-politically engaged stances surrounding them. The discourses that have shaped and sustained the aesthetic and cultural boundaries of performance practice in the classical music world have come to resist not only change, but even the idea of change. The performer's role has become fixed as the faithful transmitter of the composer's message and communities of judgment have emerged to ensure conformity with sanctioned ways of performing. (Leech-Wilkinson \& Doğantan-Dack, 2017, emphases original)

In the data, it is possible to find examples of this insistence that there is one definite way in which a piece of music must be played (see section 2.2 on perfectionism). If even musicians in the professional world are supposed to be faithful transmitters of someone else's message, as Leech-Wilkinson and Doğantan-Dack suggest, then perhaps the respondents who complain about a lack of personal expression were exposed to something similar. I wish to stress that this problem neither originates from nor is limited to Finnish music education. As Leech-Wilkinson and Doğantan-Dack (2017) point out, the idea of one true interpretation is a feature that marks all Western classical music. Teachers who insist on one single way of playing a certain piece are

\footnotetext{
11 One of the five respondents had studied both classical and pop/jazz curricula.
} 
thus following an international convention. It is quite likely that they believe themselves to be doing the best they can to coach their students and give them the necessary skills for their future music studies. However, the way this materialises in music education can be discouraging for students.

If students' creativity and personal input into music is not taken into consideration, or is considered to be non-existent, it seems clear that they cannot try to achieve distinction, i.e. original excellence. Instead, they have to settle for a competition where they can be measured with quasi-quantitative methods, by counting mistakes and other deviations from the score. I believe it would be a simplification (and quite a misunderstanding) to claim that there is no creativity in classical music practices. ${ }^{12}$ Not all of the respondents complain about such issues, and the relationship between creativity, interpretation and classical pieces is too complicated to be addressed here. However, five respondents do explicitly mention the lack of creativity. Crucially, for these respondents, the practices in their music schools, and the way they were transmitted and (unsuccessfully) communicated to students, came across as hostile to creativity. Recognition of the student as a creative agent who was capable of originality did not take place; instead, only the right kind of impersonal achievement and technical performance was appreciated. This is at odds with the explicit aims - set out in law - of basic music education.

\subsection{What counts as merit? Perfectionism at music school}

The ability to strive for distinction is important because it enables one to reflect on one's personal goals and the personal meanings of the activity, and to look for the ways in which one can do something no one else is doing. When striving for distinction, instead of competing and comparing oneself with others, the students can focus on their own 'game', and excel at it according to their own level of commitment. The trouble with classical music is that the 'game'

\footnotetext{
12 I think the issue is quite complicated. Respondents who feel that they have some say in what they are doing at music school are happy about this, and in general are more contented with their studies. Being allowed to choose the pieces they play is mentioned in six responses as a positive thing; consequently, three respondents lament not having a say or having very little say in choosing their repertoire. I believe this relative freedom enables students to express their own musical tastes and thus become an agent in their own playing, even if the teacher is teaching them traditional ways of interpreting the pieces. Students' abilities to affect the repertoire also show that there is room for negotiation in these teacher/student relationships, instead of their simply being dictated by the teacher.
} 
is often extremely limited, as described above, and there is not much room for negotiation over goals. Eleven respondents (9.4\%) write about perfectionist demands at music school. Music school students may feel, as Maiju (27) does, that 'either the difficult run [in a sonata] goes right or it goes wrong. Without the perfect execution, it is nothing'. This leaves the student with fewer avenues to find their own niche of expertise, and easily exposes them to explicit competition and comparison with others. According to Girardot, in competition the idea is to become comparable to others, and thus competition actually forces similarity (Girardot, 2011, p. 148). Under such conditions, achieving originality is rare and difficult. Niina (27) describes perfectionism as 'eating away' at what according to her should be the core function of music education: the joy of music.

In an earlier article (Elmgren, 2015), I theorised a pathology of recognition linked to the reification of merit through procedures that measure it in a supposedly objective fashion. In such procedures, merit is in constant danger of becoming an 'object', that is, reified. With the standardisation of the processes of granting merit, only certain, already established forms of excellence can be recognised as worthy of such merit. It is, then, very difficult for anything new to emerge. In music schools that teach their students to stick strictly to tradition, the threat of reification seems evident. Some respondents lament that what is played and how it ought to be played are both decided beforehand. Thus, the merits of the performance are also predetermined. It is arguable that in these situations, students are recognised only if they recreate the 'right kind' of interpretation of a piece. This prevents them from creating new meanings and new interpretations of the works. Thus, the system threatens to make its practices of recognition problematic by reifying what it considers to be merit.

\subsection{Playing one's instrument while becoming an instrument? Talent as a burden ${ }^{13}$}

The Law Concerning Basic Education in the Arts decrees that students' studies must advance from one level to the next. This guarantee of advancement also provides the justification for government subsidies of music studies (Law Concerning Government Subsidies, 2001/688). Advancement thus easily becomes understood as the main goal of music studies. This demand

\footnotetext{
13 Parts of this problematic are also dealt with in the introduction to my doctoral thesis (Elmgren, 2020).
} 
for advancement may affect teachers' attitudes towards their students. In some cases, they may favour those they see as potential future professionals, and have less regard for others (on hierarchies among music school students see Elmgren, 2019). Sometimes, however, as Elisa (20) describes, the effect is the opposite, although no less problematic: 'the teacher tried to make everyone a professional and did not understand that, for some, playing was [just] a pleasant hobby and that mediocrity was enough for me'. Merita (24) also writes: 'teachers expected that [my] career choice would be music and that music was always the top priority'. In these cases, the students' own interests were not taken into consideration. Music studies may take up a considerable amount of any student's time: in addition to instrument lessons, there may be lessons on music theory, music history, orchestra etc. Studying at music school can mean having to dedicate most of one's free time to that hobby. This is not something every student is prepared to do.

Even when a student is motivated and considered talented, as Jenni (27) was, they may face difficulties due to the ambitious goals of the institution. Jenni writes: 'due to my being talented, advancing became more of an obligation'. Olga (20) feels her teacher had 'nearly an obsession' with moulding her into a professional musician: 'I was musically talented but partly due to "forcing" by my teacher and parents I no longer had the motivation to practice and develop'.

From the recognition-theoretical point of view, this situation is interesting, as the problem is not a lack of recognition, but rather the reverse. In these cases, the students are indeed recognised as talented and promising, and teachers and parents try to push them to overcome their limits and actualise what they see as the students' potential. In the process, however, something goes wrong. The student is esteemed, yet they are also simultaneously instrumentalised vis-à-vis the goal of the musical training, that is, becoming a professional; in a way, they are made instruments of music. The students as persons are no longer the top priority; what is crucial about them is their musical potential. This is particularly clear when the student is not expected to take any part in negotiations over their studies, and not even to have a say in what they play (three respondents report not having had any say or very little say in the selection of pieces), let alone how they play it. In sum, this can add up to another hindrance to recognition, namely instrumentalisation. 


\subsection{Lack of respect in the abundance of esteem?}

As noted in the last section, in some cases the problem is not the lack of recognition - or esteem, to be precise. How can it be that an abundance of esteem still results in the student reporting a lack of motivation or stress, and/or even quitting their studies? It seems that while there may be enough esteem, there is a simultaneous lack of respect for the students as worthy negotiators in matters concerning their own lives. Respect in the context of recognition theory means equal appreciation of all as 'deontic co-authors' (Ikäheimo, 2007), or as Honneth puts it, as 'fullfledged partner[s] in interaction' (Honneth, 1992, p. 191; see also McBride, 2013). If we respect someone, we ought to see them as a person who is capable of taking part in negotiations over common norms, and for instance over what they think is good for them.

Väkevä suggests that respect in a music school context ought to be interpreted as the right of each member of society to be able to 'realize one's musical growth-potential to as full an extent as present society allows' (Väkevä, 2013, p. 58). Väkevä takes a more general view of respect in music school, and formulates it as a broad right to participate in music. Ikäheimo's and Honneth's definitions of respect are more demanding than Väkevä's suggestion: they stress that each person should also participate in the constitution of norms. The unequal treatment of music school students described by my respondents (see section 2.5 in this article, and also Elmgren, 2019) suggests that respect ought to be taken into consideration in music school practices too, not just as a general societal guideline.

Respect in school contexts is a complicated matter. Often, interactions in music school (including those to which Väkevä's article refers) take place between a teacher and a student, whose roles are not equal but hierarchical. This means that respect in education (generally, not just in music education) is more complicated than respect between, say, two adult citizens who are taking part in a political process. Now, a hierarchy between a student and a teacher may be justified and reasonable. However, as students get older, if they are to be granted respect as members of the musical community, they arguably should be included in discussions concerning how they organise their music studies in their everyday lives, as well as about what and how they play. 
As we saw in the last section, the students who complain about the lack of creativity, or who were being forced to train against their will, may still have been well recognised - esteemed, to be precise - by the institution. Their skills were appreciated, and the teachers expected great things from them. However, there may not necessarily have been an appreciation of the students' judgement. Having no say in one's studies, as one respondent writes, is also an instance where a student's judgement is overlooked. This might be understandable for small children, as their faculty of judgement has not yet developed; but with teenagers and those aged nearly 20, it seems simply disrespectful.

Doğantan-Dack and Leech-Wilkinson (2017) portray Western classical music as a tradition that was already established before the individual enters it and that will remain, hopefully unchanged, long after that individual has departed. If this is the prevailing conception among music school teachers, then the idea that students ought to take part in the constitution of the norms that guide action in music schools seems to be in stark opposition to it. The problem of the instrumentalisation of students (section 2.3) also links to disrespect for them. Claiming to recognise the talent or potential of a student can be used as a justification for treating that student as a means to an end, supposedly in their own interest, while not including them in actual negotiations concerning their hobby and their life. This results in a lack of respect for students' autonomy and inherent worth as persons. They are recognised only in relation to their musical abilities.

\subsection{Respect and hierarchies}

In music schools where respondents perceive a clear meritocratic hierarchy among students, and sometimes even among teachers (see Elmgren, 2019), the hierarchical nature of the institution may play a part in the recognition-related problematics. There may be a difficulty in including both respect and esteem in a hierarchical institution, due to its central values and practices. As these institutions aim to hone people's skills to their maximum capacity, the texts I collected show that respecting students as equals is not a self-evident state of affairs. In some institutions, there is no equality among students: some receive more attention, more 
encouragement, and even more opportunities to perform. ${ }^{14}$ However, this is not the case in all institutions: despite differences between students' skills, they can still be treated equally - for instance, in relation to others at their formal level - and given equally long lessons, equal opportunities to perform etc. ${ }^{15}$

Fourteen persons in my data write about facing hierarchies in their music school; in addition to these, two write about unequalising practices (in total, 13.7\%). This shows that students in music schools are not always treated as equals, but instead experience being placed in hierarchies with multiple levels. ${ }^{16}$ Hierarchies have a tendency to efface equality: there is no equality because some are simply better than others. Such hierarchies are considered to be meritocratic, that is, they are based on students' skills and perceived talents. Most of the respondents are unable to resist these unequal practices and believe in the meritocratic logic that is used to justify them: others have proven themselves worthy of recognition (have merited it), but they themselves have not.

Instead of respect, the form of recognition that is more likely to be available is esteem based on skills and perceived talent. The most devastating outcome of this unequal distribution of respect and esteem is the way it connects with the meritocratic undertones of the institution: the implication is that the differences in treatment are justified. They are not random preferential treatment, but are based on differences in skill that are visible at student concerts, for instance. This makes it difficult for students to stand up for themselves, as the special treatment is framed as a consequence of superior skills and talents. Maria (19), who studied the pop-jazz curriculum, describes this: 'during my time [at music school] there were a lot of skilled beginning musicians, many of them had loads of potential. Then there were also top students, exceptional talents considering their age, whose families had long roots in making and playing

\footnotetext{
14 Allowing only the best to perform is sometimes used as a reward for the most advanced students. However, as Alison Davies (2004) shows, excluding students from concerts actually means excluding them from an important learning process: preparing for the concert, dealing with the excitement, gaining experience of performing etc. Performance experience is a crucial part of a person's self-image as a musician.

15 Giving longer lessons might be considered to be justified for more advanced students, whose pieces for instance will take longer to play. But I would argue that this practice ought to be carried out not as preferential treatment but openly, equally and on the basis of formal educational goals - for instance, so that after finishing a certain diploma everyone gets longer lessons, as is already the case in some music schools.

16 For more on hierarchies in Finnish music schools, see Elmgren 2019.
} 
music'. For Maria, they simply were 'exceptional talents', even though she mentions their backgrounds and lists the unequalising practices that benefitted these 'top students'.

This combination of 1 ) institutional values that place more importance on skill and rapid advancement than on making sure that everyone has an equal opportunity to develop their skills, and 2) a meritocratic logic according to which those who are doing better deserve more than others, leads to a problematic situation where respect is a formality that can be overridden if needed.

The conflict between esteem and respect in music schools can be traced back to the tension between promoting musical values and caring for people. ${ }^{17}$ The belief (which often also appears in relation to youth sports, for example) seems to be that good results demand tracking - and that if one does not do that and instead treats everyone equally (in a way, caring for them), this risks losing the musical values the system currently helps to actualise. The tension between promoting musical values and caring for people is real, but there are ways in which it can be alleviated, by taking a different angle on what is taught and how in music schools. There is a new core curriculum in Finnish music schools (2017) that takes a more holistic view of students and places more emphasis on personal expression. This approach will more likely also help to avoid some of the recognition-related problems I have sketched in this article.

\section{Discussion and conclusions}

According to my analysis, some respondents in my study faced hindrances to recognition during their time at music school. Although the focus of this article is on Finland, it illustrates problems that stem from Western classical music's pedagogical tradition (e.g. the so-called absolute conception of music: see Brändström, 1997, cited in Numminen, 2005). The issues are thus very likely not limited to Finland, although further research is needed to confirm this.

The first hindrance is the difficulty of striving for distinction at music school. My analysis of the data demonstrates that in the music school context, attempting to distinguish oneself is often

\footnotetext{
${ }^{17}$ I would like to thank Arto Laitinen for pointing me towards this conclusion, and for this elegant formulation of the problem.
} 
only possible in a very limited sense, and for a limited group of students - i.e. those who are considered the best of the bunch.

The second possible hindrance to recognition is that recognition of something new - that is, something that transforms the norms used to assess performance, rather than simply conforming to pre-existing standards - is not usually possible in music schools. Rather, the merits of musical performance (and musical practice in general) are reified.

Another set of problems links to a lack of respect in music schools. This lack of respect may appear as disrespect for students as persons, who instead are seen as collections of admirable qualities that ought to be developed. The students may be instrumentalised in the process. They are expected to fulfil musical goals, and their autonomy and inherent (non-instrumental) value are thus overlooked. Secondly, a lack of respect can mean unequal treatment of students: where esteem is used as a justification for differential treatment, some students are given more opportunities to actualise their potential, while others are considered not to have that potential to begin with. Respect as equal treatment is overridden in this dynamic. Both those who are esteemed at music school and those who are not can face experiences where they are not respected, that is, not treated as 'full-fledged partner[s] in interaction' (Honneth, 1992, p. 191).

It seems the lack of respect in music schools is partly systemic. The law decrees that music school education should be target-oriented and advance from lower to higher levels. It thus follows that advancing in one's studies is crucial, and those who advance faster than others can be interpreted as fulfilling the purpose of music school better than others. Due to the explicit goals of music education, the pursuit of certain targets and criteria - or to put it simply, the quality of students' activities at music school - can be deemed more important than, for instance, following principles such as giving everyone a chance to perform, or giving everyone equal attention.

So what are we to do about these difficulties? One possible remedy for the difficulty of attaining distinction was present in one response: the respondent reflected that she did not remember there being much competition in her music school, and then pointed out that she and her friends had mostly played different instruments. It is arguable that this resulted in the ability of each student to focus on their own 'game' instead of competing with the others. This respondent's 
positive experiences were also partly created by her spontaneously formed friendships. Friendship is a form of recognition, and it seems clear that its role ought to be further investigated in the music school context in the future. It might be possible for institutions to help students who play different instruments to get to know each other by encouraging them to play music in small groups. This would both make each player the only expert on their own instrument in the group and enable the birth of friendships between players of different instruments.

My research suggests that it would be beneficial for students to be more routinely included in discussions concerning both how they organise their music studies in their lives and what and how they play. If the new (2017) core curriculum makes the studies more flexible and negotiable for students, this might better enable them to strive for distinction, and it might also alleviate the reification of merit. If this were to happen, it might no longer be a problem that not everyone can become a professional violinist or R 'n' B singer, for instance (for various reasons, including economic and societal ones, and not, as is often thought, because not everyone has equal 'talent'). Instead, students would be able to pursue their own goals, driven by their internal motivation, without having to focus on their place in a hierarchy or all compete in a non-negotiable game that inevitably directs attention towards the players' differences in skill and 'level'. In a system like this, the excellences that students might achieve could become more various. Not everyone is skilled in relation to the norms that currently govern classical music. However, if the structure and content of studies were to change so that excelling in a certain way would no longer be the only possible goal, then people's different abilities and motivations would have a chance to emerge. Caring for people in the context of studying music would mean helping them to find the musical values they can and want to promote.

\section{Appendix: call for contributions (translation from Finnish)}

\section{Beta blockers before student concerts, or the key to finding your own field?}

Did you study in a Finnish music school during the period 1995-2015? I am collecting research data on Finnish youth and young adults' experiences of music school for my thesis, in which I am studying meritocracy. 
In meritocratic practices, such as aptitude tests, competitions and the hierarchies based on them, the crucial thing is the ability to exclude some (who do not show merit) and include others (who have merit). One gets into music school through an entrance examination. This means that for those who get in, the first point of possible exclusion has been passed. Some students end up as professional musicians, and some quit their studies during their teenage years and refuse to touch their instrument again for years, if ever. What happens during one's time in music school? Puberty alone cannot be the explanatory factor, as it does not deter all beginning musicians.

I examine the inclusions and exclusions that take place at music school. I am looking for accounts of both nice and unpleasant experiences at music school. Which factors played a part in what happened to you and your musical hobby? Which practices at music school, and which ways of studying music, motivated you to continue the hobby? Did some practices or ways of studying affect your motivation to practice negatively? What conception did you develop of yourself as a musician during your studies?

In music schools, students may be encouraged to advance in their music studies in many different ways. The most advanced students may be rewarded, for instance, with encouragement grants, opportunities to perform, longer lessons, and masterclasses given by special teachers... Were these or other types of encouragement used in your music school? How did you experience these practices, and did you get to be involved in them, or were you left outside?

Was there competition or (explicit or implicit) comparison among the students in your music school? What was the teachers' part in creating the atmosphere in the music school? Were they aware of possible competition? Did you feel that your motivation, application and talent were recognised, and that you could advance in your music studies in the way you wished?

Write freely about your experiences. The writing may be a short description of a single situation or an incident linked to music studies, or it can be a wider text charting your life, your music as a hobby and your music studies. I am asking all the writers to also fill out a preliminary information form, which seeks background information that is important for the study. If you wish, you may also provide your contact information on the preliminary information form. 
Those who provide their contact information will be entered into a lottery, with 15 cinema tickets offered as prizes.

\section{References}

Alasuutari, P. (2012). Laadullinen tutkimus 2.0 [Qualitative research 2.0]. Vastapaino.

Alt, S., Enakimio, K., Meriluoto, S., \& Rodionoff, N. (2017). Opetushallitus [Finnish National Agency for Education]. https://www.oph.fi/fi

Aluehallintovirasto. (2012). Taiteen perusopetuksen alueellinen saavutettavuus 2012. [Regional availability of basic education in the arts]. https://www.avi.fi/documents/10191/52019/Taiteen+perusopetuksen+alueellinen+saavute ttavuus+2012/04fff831-7505-4d85-96bf-c0f3bd9ff8ed

Andersson, P., \& Fejes, A. (2010). Mobility of knowledge as a recognition challenge: Experiences from Sweden. International Journal of Lifelong Education, 29(2), 201-218.

Blodget, A. S., Fischer, K. , Immordino-Yang, M. H. and Schneps, M. H. (2011.) Neuroscience and the Classroom: Making Connections. A video course for K-12 educators organized by Science Media Group at the Harvard-Smithsonian Center for Astrophysics, in association with the Mind, Brain, and Education programme at the Harvard Graduate School of Education, the Brain and Creativity Institute, and the Rossier School of Education at the University of Southern California. www.learner.org/courses/neuroscience

Brändstöm, S. (1997.) Vem är musikalisk? Intervjuer med musiklärare och musiklärarutbildare. [Who is musical? Interviews with music teachers and music teacher educators] Pedagogiska Publikationer från Kungliga Musikhögskolan, 3.

Davies, A. (2004). Preparing professional performers: Music students' perceptions and experiences of the learning process at Birmingham Conservatoire. International Journal of Qualitative Studies in Education, 17, 803-821. 
Elmgren, H. (2015). "Recognition and the ideology of merit." 2015. Studies in Social and Political Thought, 25 Special Issue on Pathologies of Recognition. Sussex: Brighton Students and Faculty of the Graduate Programme in Social and Political Thought, University of Sussex.

Elmgren, H. (2018). “Merit, Competition, Distinction.” Redescriptions: Political Thought, Conceptual History and Feminist Theory, 21 (1), 71-89.

Elmgren, H. (2019). "Merit-based exclusion in Finnish music schools.” International Journal of Music Education, 37 (3), 425-439.

Elmgren, H. (2020). On the Problematic of Meritocracy. 2020. JYU Dissertations 185. University of Jyväskylä.

Fleming, T. (2014). Axel Honneth and the struggle for recognition: Implications for transformative learning. In A. Nicolaides \& D. Holt (Eds), Spaces of transformation and transformation of space: Proceedings of the XI International Transformative Learning Conference (pp. 318-324). Columbia University, Teachers College.

Fraser, N. (2003.) Social Justice in the Age of Identity Politics: Redistribution, Recognition, and Participation' in Nancy Fraser and Axel Honneth, Redistribution or Recognition? A PoliticalPhilosophical Exchange (pp. 7-109). Verso.

Freyenhagen, F. (2015). Honneth on social pathologies: A critique. Critical Horizons, 16, 131152.

Girardot, D. (2011). La Société du mérite: Idéologie méritocratique et violence néolibérale. Le Bord de l'eau.

Hanhela, T. (2014.) Educational perspectives on recognition theory. Acta Universitatis Ouluensis. E, Scientiae rerum socialium 149. University of Oulu.

Hirvonen, 0. (2018). On the ontology of social pathologies. Studies in Social and Political Thought, 28, 9-14. 
Honneth, A. (1992). Integrity and disrespect: Principles of a morality based on the theory of recognition. Political Theory, 20, 187-201.

Honneth, A. (1995). Struggle for recognition. MIT Press.

Huttunen, R. (2009). Habermas, Honneth and education: The significance of Jürgen Habermas' and Axel Honneth's critical theories to education. Lambert Academic Publishing.

Ikäheimo, H. (2015). Conceptualizing causes for lack of recognition: Capacities, costs and understanding. Studies in Social and Political Thought, 25, 24-43.

Ikäheimo, H. (2007.) Recognizing persons. Journal of Consciousness Studies, 14(5-6), 224-247.

Immordino-Yang, M.H. \& Damasio, A. (2007.) We Feel, Therefore We Learn: The Relevance of Affective and Social Neuroscience to Education. Mind, Brain \& Education 1(1), 3-10. https://onlinelibrary-wiley-com.ezproxy.jyu.fi/doi/epdf/10.1111/i.1751-228X.2007.00004.x

Kangas, A., \& Halonen, K. (2015). Taidekasvatuksen ja -koulutuksen tavoitteet ja haasteet [The goals and challenges of arts education]. In I. Heiskanen, A. Kangas, \& R. Mitchell (Eds), Taiteen ja kulttuurin kentät (pp. 191-230). Tietosanoma.

Laitinen, A. (2015). Social pathologies, reflexive pathologies, and the idea of higher-order disorders. Studies in Social and Political Thought, 25, 44-65.

Laitinen A.; Särkelä A.; Ikäheimo H. (2015). Pathologies of Recognition: An Introduction. Studies in Social and Political Thought 25, 3-24.

http://journals.sussex.ac.uk/index.php/sspt/article/view/44/39

Law Concerning Basic Education in the Arts 1998/633. http://www.finlex.fi/fi/laki/ajantasa/1998/19980633 
Law Concerning Government $\quad$ Subsidies http://www.finlex.fi/fi/laki/ajantasa/2001/20010688\#L2P5

Leech-Wilkinson, D., \& Doğantan-Dack, M. (2017). Classical performance culture: Beyond the limits [Keynote presentation]. Musical Cultures Conference, 3-5 April 2017, Hull, UK.

McBride, C. (2013). Recognition. Polity Press.

Numminen, A. (2005). Laulutaidottomista kehittyviksi laulajiksi [From poor pitch singers to developing singers] [Doctoral thesis, Sibelius Academy]. Studia Musica 25. Sibelius Academy.

Riediger, M., Eicker, G., \& Koops, G. (2010). Music schools in Europe - Musikschulen in Europa les écoles de musique en Europe [Report]. European Music School Union. http://www.musicschoolunion.eu/wpcontent/uploads/2016/08/101115 EM publicatie EM $\underline{\mathrm{U}} 2010$ digitaal.pdf

Säilävaara, J. (2016). Imettämässä kaapissa? Pitkään imettäneet äidit ja normatiiviset tilat [Breastfeeding in the closet? Mothers who practice extended breastfeeding, and normative spaces]. Sukupuolentutkimus, 29(2), 7-20.

Sandberg, F. (2016). Recognition and adult education: An incongruent opportunity. Studies in Continuing Education, 38(3), 265-280.

Saresma, T. (2010). Kokemuksen houkutus [Temptation of 'experience']. In T. Saresma, L.-M. Rossi, \& T. Juvonen (Eds), Käsikirja sukupuoleen (pp. 59-74). Vastapaino.

Särkelä, A. (2008). Good, evil and successful recognition: A processualist view on recognitive attitudes, relations and norms. Nordicum-Mediterraneum: Icelandic E-Journal of Nordic and Mediterranean Studies, 8(2). https://nome.unak.is/wordpress/08-2/c58-conferencepaper/good-evil-and-successful-recognition-a-processualist-view-on-recognitive-attitudesrelations-and-norms/ 
Silvasti, T. (2014). Sisällönanalyysi [Content analysis]. In I. Massa (Ed.), Polkuja yhteiskuntatieteelliseen ympäristötutkimukseen (pp. 33-48). Gaudeamus.

Sprung, A. (2013). Adult education in migration societies and the challenge of 'recognition' in Austrian and German adult education. Studies in the Education of Adults, 45(1), 82-98.

Statista. (2017a). Number of Facebook users in the United States as of January 2017, by age group (in millions). https://www.statista.com/statistics/398136/usfacebook-user-agegroups/

Statista. (2017b). Total number of Facebook users in the United Kingdom (UK) in January 2017, by age group and gender (in millions). https://www.statista.com/statistics/507417/number-of-facebook-users-in-theunitedkingdom-uk-by-age-and-gender/

Stojanov, K. (2018). Education, self-consciousness and social action: Bildung as a neo-Hegelian concept. Routledge.

Suomen Musiikkioppilaitosten liitto. (2017). Suomen Musiikkioppilaitosten liitto [The Union of Finnish Music Schools]. http://www.musicedu.fi

Väkevä, L. (2013). Struggling musicians: Implications of the (Hegelian) philosophy of recognition for music education. Philosophy of Music Education Review, 24(1), 45-64. 